\title{
Perancangan Dan Implementa Sisistem Infomrasi Penjualan Pada minimarket Palm Mart Berbasis Multi Tier
}

\author{
Sabilla Royan $^{1}$, Irwansyah ${ }^{2}$, Suryayusra ${ }^{3}$ \\ ${ }^{1,3}$ Informatics Department, Bina Darma University, Palembang, Indonesia \\ ${ }^{2}$ Computer Engineering Department, Bina Darma University, Palembang, Indonesia \\ Email: ${ }^{1}$ sabilaroyan@gmail.com, ${ }^{2}$ irwansyah@ binadarma.ac.id, ${ }^{3}$ suryayusra@ binadarma.ac.id
}

\begin{abstract}
The Mini Market Palm Mart, which can be a market for sellers, is addressed in Housing Ogan Permata Indah, Jalan Opi Raya, Jakarta, Palembang. Palm Mart has 6 employees, where they have their respective roles, namely a cashier, 2 shopkeepers and arranging items at the Palm mart and 2 warehouse guards and 1 administration. From year to year, Palm Mart mini-market stores have experienced an increase but it is very limiting for sellers to place their merchandise in Palm Mart Stores, thus impacting on the amount of data processed and the quality of service to consumers. The solution to the problems that exist in Palm Mart Stores is by creating a multitiered sales information system to help employees at the Palm Mart. At this writing the author uses descriptive research methods and uses the method of developing the waterfall system and uses Unified Modelling Language analysis.
\end{abstract}

Keywords: Multi-Tier, Palm Mart Store, Web

\section{PENDAHULUAN}

Saat ini semua bidang hampir membutuhkan komputer sebagai alat bantu karena mempunyai banyak kelebihan dari segi ketelitian dan kecepatan, misalnya bidang pendidikan, bidang ekonomi baik digunakan oleh swasta maupun pemerintahan. Manfaat yang ada sangat besar, baik dalam ketelitian, kecepatan maupun volume pekerjaan yang ditangani dan dapat memperoleh informasi dan laporan dengan cepat dan tepat tanpa melalui proses pencatatan yang berulang-ulang.

Toko Mini Market Palm Mart merupakan sebuah toko dimana terdapat beberapa pemasok sehingga palm mart dapat menjadi sebuah media untuk para pengguna dalam menjualakan produk-produk yang ada dari para pelanggan atau para penjual yang telah menjadi member resmi palm mart. Akan tetapi palm mart yang ini hanya sebatas toko mini yang menjual produk- 
produk kebutuhan rumah tangga seperti kebutuhan mandi, perawatan tubuh, pembersih dan lain sebagainya.

Mini Market Palm Mart yang dapat menjadi market untuk para penjual ini beralamatkan di Perumahan Ogan Permata Indah jalan opi raya, jakabaring Kota Palembang. Palm Mart memiliki karyawan sebanyak 6 orang, dimana diantar mereka memiliki peranan masing-masing yaitu seorang kasir, 2 orang penjaga toko serta mengatur tempat barang-barang yang ada di Palm mart dan 2 orang penjaga gudang dan 1 administrasi. Dari tahun ke tahun toko mini market Palm Mart mengalami peningkatan akan tetapi sangat membatasi para penjual untuk meletakan barang dagangan mereka di Toko Palm Mart, sehingga berdampak pada jumlah data yang diolah dan kualitas pelayanan kepada konsumen.

Berdasarkan latar belakang diatas maka dari itu Palm Mart membutuhkan sebuah sistem yang dapat digunakan untuk memperluas market yang ada di Palm Mart sehingga dapat lebih efektif dan efisien,maka penulis menuangkan penelitiannya dalam bentuk penulisan ini yang berjudul "Perancangan Dan Implementasisistem Infomrasi Penjualan Pada Minimarket Palm Mart Berbasis Multi Tier".

\section{METODOLOGI PENELITIAN}

Adapun tahapan yang dilakukan penulis dalam merancang dan membangun system informasi penjualan pada Toko Palm Mart berbasis multi-tier, menggunakan metode pengembangan sistem air terjun atau yang sering disebut watterfall, yaitu sebagai berikut:

\section{Requirement Analisis}

Tahapan awal yang dilakukan penulis, yaitu menganalisis permasalahan yang ada, melakukan identifikasi masalah-masalah pokok yang ada, guna menjadi dasar kelompok atau organisasi sehingga terjadi perubahan, untuk pengembangan sistem informasi penjualan pada Toko Palm Mart Palembang Berbasis multi-tier, pada tahap ini peneliti mengidentifikasi kebutuhan user atau pengguna akan sistem informasi penjualan pada Toko Palm Mart Palembang Berbasis Multi-Tier, ditempuh dengan cara mengadakan wawancara mendalam kepada user atau pengguna, obesrvasi pada system yang sedang berjalan di Toko Palm Mart dan pihak-pihak yang terkait langsung maupun yang tidak terkait langsung pada Toko Palm Mart dengan pengembangan sistem informasi penjualanan pada Toko Palm Mart Palembang Berbasis Multi-Tier. 


\section{System Design}

System Desaign yaitu bagaimana cara penulis mendesain sistem yang akan diterapkan di Toko Palm Mart Palembang, dengan memanfaatkan software HTML5 dan Javascript untuk membuat tampilan desain website Toko Palm Mart Palembang berbasis Web Responsive serta bagaimana penulis membuat tampilan dan system menjadi lebih mudah dipahami oleh admin Toko Palm Mart, Admin Gudang Palm Mart serta para pemasok yang ada di toko Palm Mart Palembang. Pada tahap ini penulis membuat coding bertahap dengan menggunakan software Dreamweaver CS5, dan datebase MySQL. Tahap ini penulis menerapkan analisis yang telah dibuat di tahap pertama, pada tahap analisis ini jika terjadi kesalahan pada analisis maka system desain tidak boleh dilanjutkan, karena harus ,mengulang dari tahap pertama, dan harus diperbaiki pada tahap analisis.

\section{Implementation}

Pada tahap ini, penulis menerpakan system informasi yang dibuat untuk Toko Palm Mart Palembang kepada para admin di toko, admin gudang serta pemasok tersebut agar dapat diketahui kesalahan yang ada di system serta pembelajaran untuk admin dalam menggunakan system. System yang dibuat sudah dapat diterapkan akan tetapi pada tahap ini bias dilakukan uji coba terlebih dahulu, sehingga apa bila ingin diperbaiki maka penulis dapat memperbaiki tahap ini tanpa harus mengulang pada tahap analisis sebab pada tahap ini sering terjadi kesalahan atau perbaikan di desain sistem tanpa harus mengulang ke tahap perbaikan analisis.

\section{Integration \& Testing}

Pada tahap ini merupakan tahap penyelsaian system, karena pada tahap ini system informasi sudah siap diuji oleh hal layak banyak dan telah dapat di integrasikan kedalam jaringan internet sehingga mudah diakses oleh masyarakat banyak.

\section{Operation \& Maintenance}

Pada tahap ini merupakan tahap akhir penyelsaian system, karena pada tahap ini system informasi sudah siap dijalalankan dan digunakan oleh hal layak banyak dan pada tahap ini mempertegaskan bahwa perlunya pembaruan dan pemeliharaan system. Pada tahap ini jika terddapat kesalahan maka ada perbaikan sistem yang harus dilakukan dari awal. Biasanya untuk tahap ini tidak sulit karena pada tahap ini hanya butuh pengembangan sistem jika ingin 
diperbaiki. Tahap ini merupakan tahap pengenalan sistem kepada hal layak banyak jika pada tahap ini gagal maka untuk tahap operasi harus diulang dari awal tetapi jika tahap ini dapat diterima maka pada tahap ini hanya butuh perawatan sistem yang dapat digunakan oleh penulis selanjutnya.

\section{HASIL DAN PEMBAHASAN}

\subsection{Kebutuhan}

Kebutuhan sistem informasi sesuai dengan proses yang telah dikemukakan pada proses pegnembangan dapat dilihat pada Gambar 1 dan Gambar 2 yang merupakan diagram use case dan diadram activity.

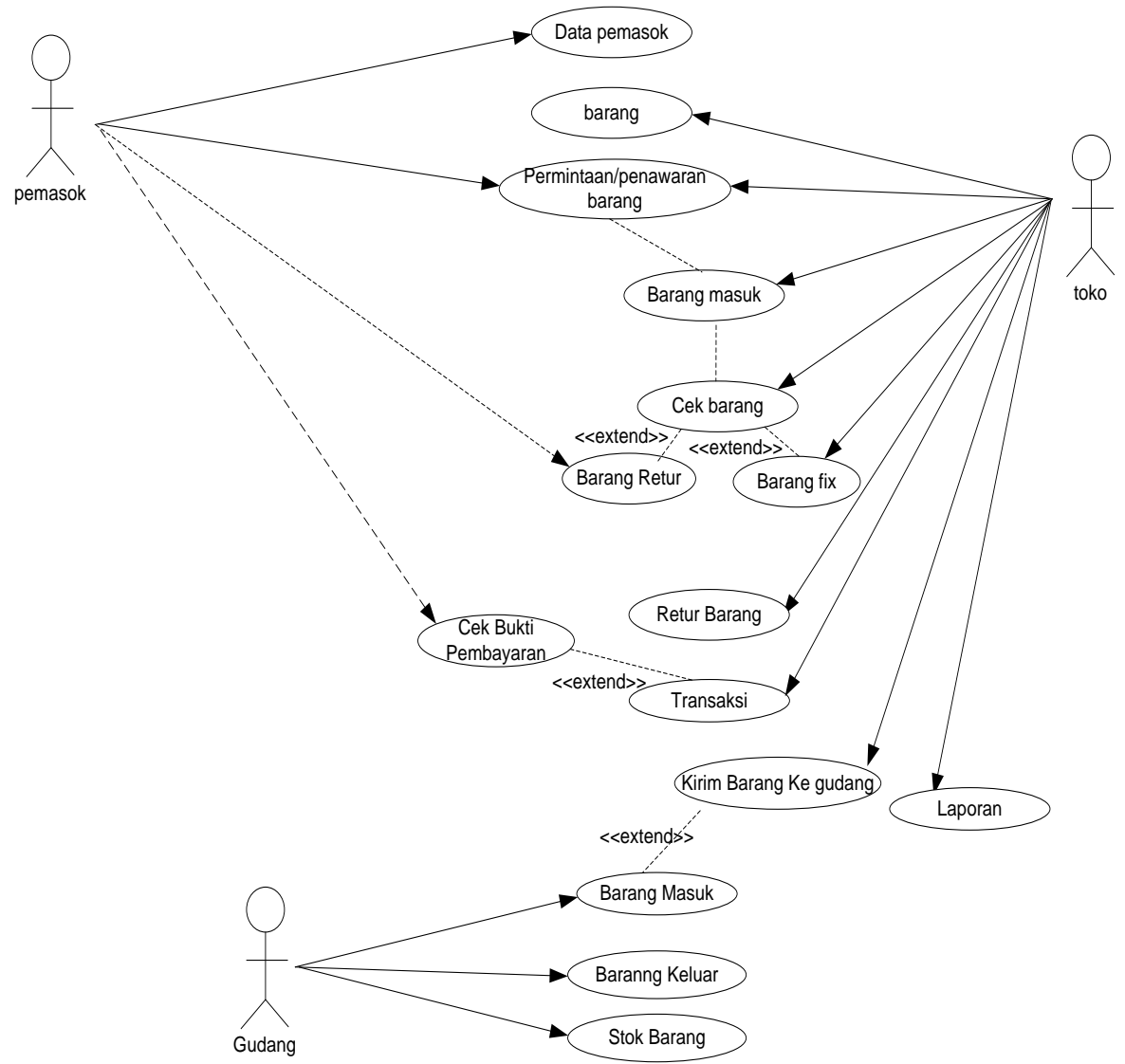

Gambar 1. Rancangan Usecase Diagram 
http://journal.jis-institute.org/index.php/jpsii/index

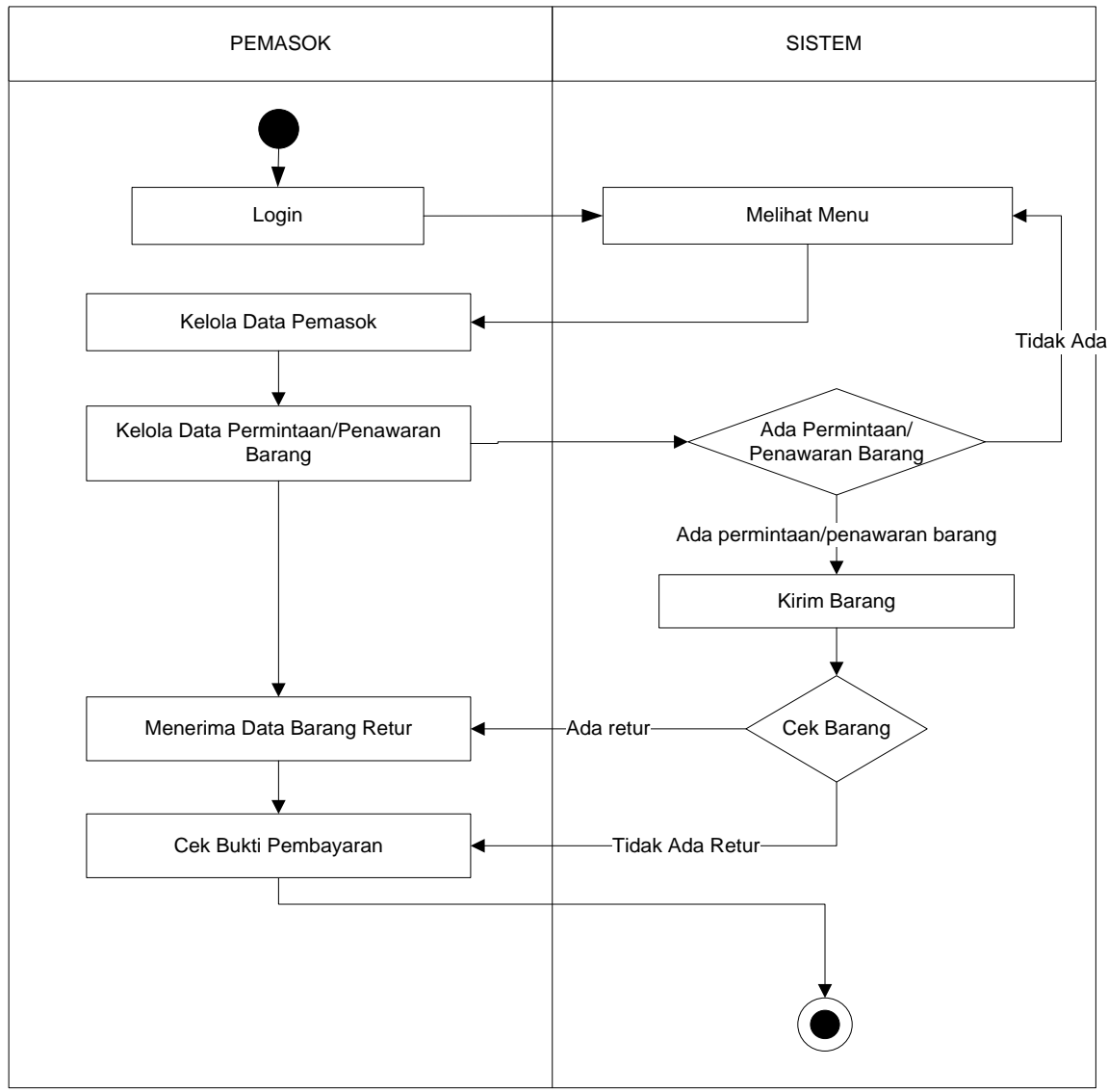

Gambar 2. Rancangan Activity Diagram

\subsection{Hasil Pengembangan}

Berikut dapat dijelaskan hasil pengembangan sistem informasi sesuai dengan prosedur pengembangan dan kebutuhan sistem informasi

\section{Halaman Login}

Pada halaman merupakan halaman yang menampilkan data link setiap user yang akan menggunakan program atau sistem yang dibuat oleh Toko Palm Mart sehingga halaman ini dapat digunakan oleh Pemasok, Gudang dan Toko, Pada halaman ini juga menampilkan sebuah input data yang terdiri dari username dan password, dimana pada input data tersebut digunakan sebagai pengamanan untuk masuk setiap halaman user. 


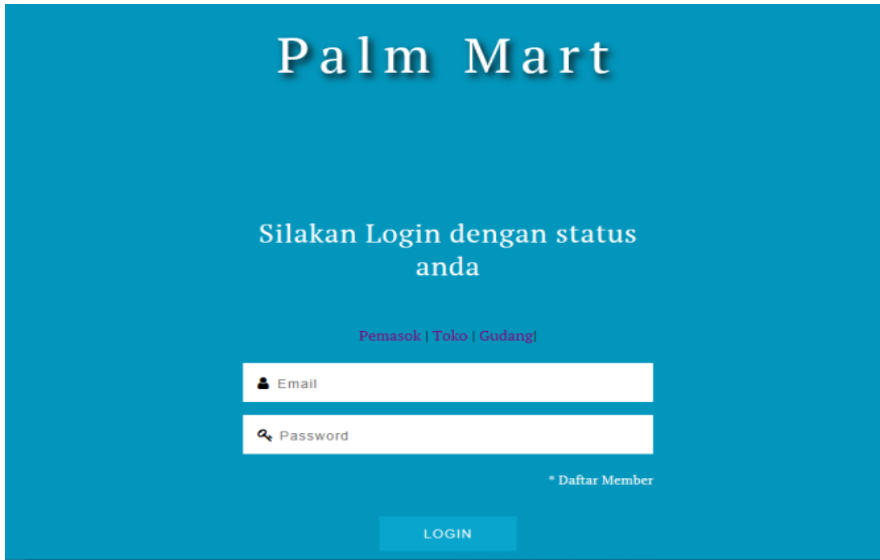

Gambar 2. Halaman Login User

2. Penjelasan halaman bagian pemasok

Halaman ini digunakan oleh pemasok dan hanya menampilkan data-data pemasok yang bersangkutan dengan username dan password sehingga setiap pemasok yang ada di Toko Palm Mart tidak saling melihat pengolahan data masing-masing.

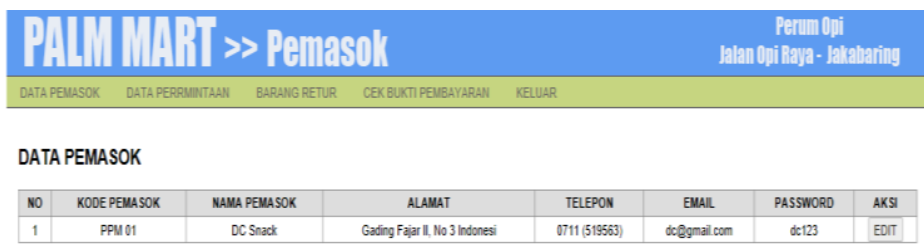

Gambar 3. Halaman Data Pemasok

\section{Halaman Data Permintaan}

Pada halaman ini digunakan untuk menampilkan data-data permintaan yang dilakukan gudang ke bagian pemasok sehingga pada halaman ini dapat digunakan sebagai patokan untuk mengirim barang ke bagian gudang. Pada halaman ini juga dilengkapi link untuk mengirim data barang ke gudang. 


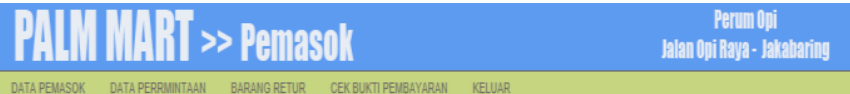

DATA PERMINTAAN

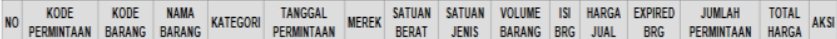

Gambar 4. Halaman Data Permintaan

\section{Halaman Data Barang Retur}

Pada halaman ini digunakan sebagai data barang retur yang ada di gudang, dan dikirimkan oleh bagian gudang ke bagian pemasok agar pemasok mengetahui kerusakan barang yang terjadi di bagian gudang pada saat pengiriman barang.

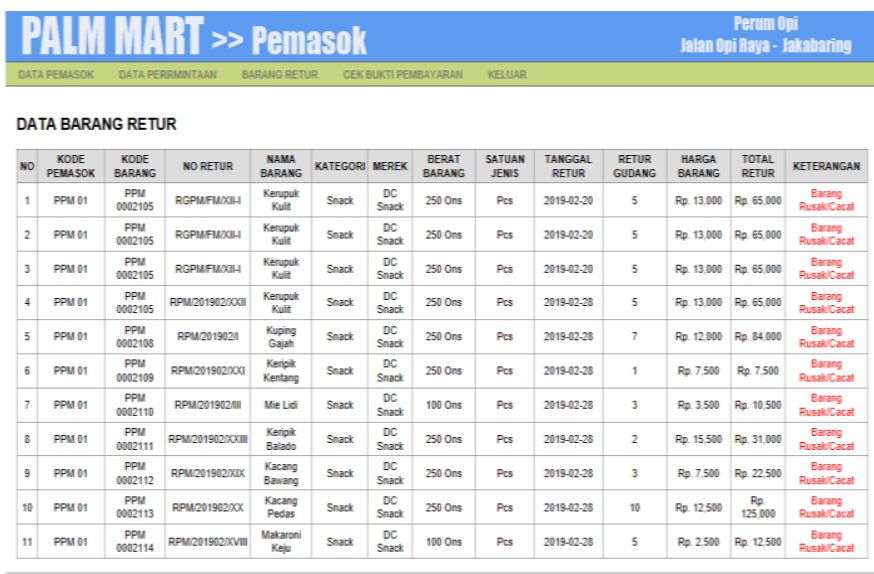

Gambar 5. Halaman Retur Barang

\section{Halaman Cek Bukti Pembayaran}

Halaman ini digunakan untuk menampilkan data-data bukti pembayaran yang telah dilakukan oleh aplm mart kepada para pemasok yang bekerja sama dengan mini market palm mart. 
http://journal.jis-institute.org/index.php/jpsii/index

\begin{tabular}{|c|c|c|c|c|c|c|c|c|c|}
\hline P & Diviti & \multicolumn{5}{|c|}{$\gg$ Pemasok } & \multicolumn{3}{|c|}{$\begin{array}{l}\text { Periun Opi } \\
\text { Jalan opi llaya - Iatabaring }\end{array}$} \\
\hline DATA FEDASOK & 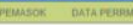 & 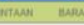 & WO RETUR & EKRUKTIPEMEAKA & HEAH RELAA & & & & \\
\hline \multicolumn{10}{|c|}{ BUKTI DATA PEMBAYARAN } \\
\hline mo & NO PENGIRIIUAN & KODE GARANG & MAMA BARANG & TANGGal KIRAM & JUMLAH EARANG & MARGA GARANG & TOTAL HARGA & KEIERANGAN & BUKTI BAYAR \\
\hline , & apu 24 & PPM 0002114 & Mataroni Kein & $2019 \cdot 02.28$ & 193 & RQ 2.2500 & Re. 225000 & & 므 \\
\hline 2 & OPU 22 & PPM 0002112 & Kacang Bewang & $2019 \cdot 02.28$ & 246 & AQ 7.500 & RQ 500.000 & & 口 \\
\hline , & opa is & PPM 000z110 & Me Las & 2011002.20 & 92 & Ro 3.300 & Re. 250.000 & & घ \\
\hline 4 & OPA w & PPM 0002100 & Kupmo ospem & $2019 \cdot 02.2 \mathrm{a}$ & 92 & AQ 12.000 & RQ Gr.000 & & घ \\
\hline s & apd 22 & PPM 0002113 & Kacemp Peseses & $2019 \cdot 02.20$ & 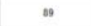 & AQ 12.500 & $R_{Q} 750,000$ & & 마 \\
\hline - & GPU 20 & PPM 0002211" & Kenpa Batado & 201902.28 & 197 & RQ. 15.500 & RQ 050.000 & & 口 \\
\hline , & OPMIY & PPM 0002109 & Kenge Kentano & $2019-92-20$ & " & PQ 7.500 & $R_{Q}, 500.000$ & & 모 \\
\hline . & apo 10 & PPM 0002205 & Kenves Kuit & 2011202.20 & 211 & $\mathrm{Ag}_{0} 13000$ & Re. 750.000 & Lunas & $y$ \\
\hline , & MNV.GPW - 0002Z12013-01-014 & PFM 0002104 & Kacang Palono & 201902.14 & 197 & Ap 7500 & RQ 500.000 & & घ \\
\hline 10 & Opto ou & PPM 0002101 & Matasoni & $0000-00 \cdot 00$ & 196 & AQ 9750 & FQ $1,300,000$ & & 口 \\
\hline " & GPN 02 & PPM 0002102 & Ahat & 00000.00 .00 & 267 & AQ 7.125 & FQ 1900.000 & & 口 \\
\hline
\end{tabular}

Gambar 6. Halaman Data Cek Bukti Pembayaran

6. Halaman Gudang,

berikut beberapa halaman yang digunakan oleh gudang yaitu terdiri dari Halaman Stok Barang berfungsi untuk mengecek data stok barang yang ada di Toko Palm Mart Pada Halaman ini gudang dapat menegcek barang-barang yang masih ada di gudang maupun sudah tidak ada lagi.

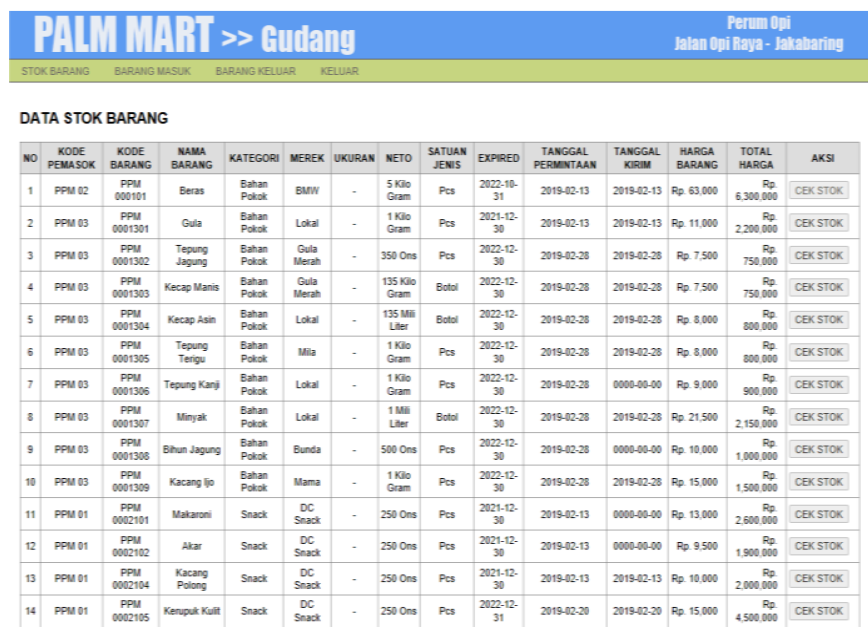

Gambar 7. Halaman Stok Gudang

7. Halaman Data Masuk

Pada halaman ini merupakan halaman yang digunakan untuk barang-barang yang telah dikiri toko ke gudang sebagai stok untuk toko. 


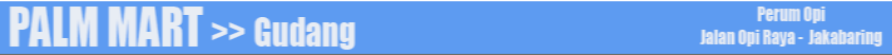

\begin{tabular}{|c|c|c|c|c|c|c|c|c|c|c|c|c|c|c|}
\hline so & $\begin{array}{c}\text { KODE } \\
\text { PEMASOK }\end{array}$ & $\begin{array}{c}\text { KODE } \\
\text { BARANG }\end{array}$ & $\begin{array}{l}\text { NAMA } \\
\text { BARANG }\end{array}$ & KATEGORI & $\begin{array}{l}\text { TANGGAL } \\
\text { PERMNTAAN }\end{array}$ & MEREK & $\begin{array}{l}\text { SATUAN } \\
\text { JENIS }\end{array}$ & $\begin{array}{l}\text { VOLUME } \\
\text { BARANG }\end{array}$ & ISI BRG & $\begin{array}{l}\text { HARGA } \\
\text { BARANG }\end{array}$ & $\begin{array}{l}\text { EXPREED } \\
\text { BRG }\end{array}$ & $\begin{array}{c}\text { JUMLAH } \\
\text { PERUENTAAN }\end{array}$ & $\begin{array}{l}\text { TOTAL } \\
\text { HARGA }\end{array}$ & AKSI \\
\hline 1 & PPM 05 & $\begin{array}{l}\text { PPU } \\
000501\end{array}$ & Elue Band & $\begin{array}{l}\text { Bahan } \\
\text { Polkok }\end{array}$ & $2019-03-04$ & $\begin{array}{l}\text { Blue } \\
\text { Band }\end{array}$ & Kaleng & - & $2500 \mathrm{~ms}$ & $\begin{array}{r}R_{p} \\
11,000\end{array}$ & $2022-12-$ & 100 & $\begin{array}{r}P_{p} \\
1,100,000\end{array}$ & $\begin{array}{l}\text { Krim } \\
\text { Barang }\end{array}$ \\
\hline 2 & PPM 01 & $\begin{array}{l}\text { PPU } \\
\text { po02114 }\end{array}$ & $\begin{array}{l}\text { Makarani } \\
\text { Kejp }\end{array}$ & Snack & $2019-02-28$ & $\begin{array}{c}\text { DC } \\
\text { Snack }\end{array}$ & Pes & - & 10000ns & $P_{q} .4500$ & ${ }^{20202-12-2}$ & 200 & $\begin{array}{rl}R & R \varphi \\
900,000\end{array}$ & $\begin{array}{l}\text { Krim } \\
\text { Barang }\end{array}$ \\
\hline 3 & Ppu 01 & $\begin{array}{l}\text { PPIM } \\
\text { P002113 }\end{array}$ & $\begin{array}{l}\text { Kacang } \\
\text { Pedsas }\end{array}$ & Snack & $2019-02-28$ & $\begin{array}{l}\text { DC } \\
\text { Snack }\end{array}$ & Pes & - & $2500 \mathrm{~ms}$ & $\begin{array}{r}P_{Q} \\
15.000\end{array}$ & 20201-12- & 100 & $\begin{array}{r}R p \\
1,500,000\end{array}$ & $\begin{array}{l}\text { Krim } \\
\text { Barang }\end{array}$ \\
\hline 4 & PPQ 01 & $\begin{array}{c}\text { PPU } \\
0002112\end{array}$ & $\begin{array}{l}\text { Kacang } \\
\text { Barang }\end{array}$ & Snack & $2019-0228$ & $\begin{array}{c}\text { DC } \\
\text { Snack }\end{array}$ & Pes & - & $2500 \mathrm{~ms}$ & $\begin{aligned} F_{Q} \\
10,000\end{aligned}$ & $20202-12-$ & 250 & $2500,0.000$ & $\begin{array}{l}\text { Krim } \\
\text { Barang }\end{array}$ \\
\hline 5 & PPu 01 & $\begin{array}{l}\text { PPU } \\
\text { pooz2111 }\end{array}$ & $\begin{array}{l}\text { Keripia } \\
\text { Balasolo }\end{array}$ & Snack & $2019-02-28$ & $\begin{array}{l}\text { DC } \\
\text { Snack }\end{array}$ & Pos & - & 2500 ns & $\begin{array}{r}P_{Q} \\
17,000\end{array}$ & $\frac{2022-12-}{30}$ & 200 & $\begin{array}{r}P Q \\
3,400,000\end{array}$ & $\begin{array}{c}\text { Krim } \\
\text { Brang }\end{array}$ \\
\hline 6 & PPM 01 & $\begin{array}{l}\text { PPU } \\
\text { o002109 }\end{array}$ & $\begin{array}{l}\text { Keilidi } \\
\text { Kentang }\end{array}$ & Snack & $2019-02-28$ & $\begin{array}{c}\text { DC } \\
\text { Snack }\end{array}$ & $\mathrm{PC}$ & - & 60ns & $\begin{array}{r}\mathrm{PQ}_{\mathrm{p}} \\
10,000\end{array}$ & $\begin{array}{c}2022-12-2 \\
30\end{array}$ & 100 & $\begin{array}{r}R p \\
1,000,000\end{array}$ & $\begin{array}{l}\text { Krim } \\
\text { Barang }\end{array}$ \\
\hline 7 & PPM 01 & $\begin{array}{l}\text { PPI } \\
0002110\end{array}$ & Melí & Snack & $2019-02-28$ & $\begin{array}{l}\text { DC } \\
\text { Snack }\end{array}$ & Pas & - & $1000 \mathrm{~ms}$ & $R_{Q}, 5,000$ & $\frac{2022-12 .}{30}$ & 100 & $\begin{array}{r}R \varphi \\
500.000\end{array}$ & $\begin{array}{l}\text { Krim } \\
\text { Barang }\end{array}$ \\
\hline 8 & PPW 01 & $\begin{array}{l}\text { PPU } \\
\text { 0002108 }\end{array}$ & Kuping Gajizh & Snack & $2019-02-28$ & $\begin{array}{c}\text { DC } \\
\text { Snadk }\end{array}$ & Pes & - & $2500 \mathrm{~ms}$ & $\begin{array}{r}P_{Q} \\
13.500\end{array}$ & $\begin{array}{c}2022-12-2 \\
30\end{array}$ & 100 & $\begin{array}{r}P_{p} \\
1,350,000\end{array}$ & $\begin{array}{l}\text { Krim } \\
\text { Barang }\end{array}$ \\
\hline 9 & PPw 03 & $\begin{array}{l}\mathrm{PPM} \\
0001302\end{array}$ & $\begin{array}{l}\text { Tepung } \\
\text { Jagung }\end{array}$ & Polok & $2019-02.28$ & $\begin{array}{l}\text { Gula } \\
\text { Werah }\end{array}$ & P & - & $3500 \mathrm{~ms}$ & PQ. 7.500 & $\frac{2020-12-2}{30}$ & $\infty$ & $\begin{array}{r}R_{\varphi} \\
750,000\end{array}$ & $\begin{array}{l}\text { Krim } \\
\text { Barang }\end{array}$ \\
\hline 10 & PPM 03 & $\begin{array}{l}\text { Ppu } \\
\text { p001303 }\end{array}$ & Kecap Manis & $\begin{array}{l}\text { Bahan } \\
\text { Polokik }\end{array}$ & $2019-02-28$ & $\begin{array}{l}\text { Gula } \\
\text { Werah }\end{array}$ & Botal & - & $\begin{array}{l}\text { 135rcio } \\
\text { Gram }\end{array}$ & Rp. 7.500 & $\frac{2022-12-}{30}$ & 100 & $\begin{array}{l}R p \\
750,000\end{array}$ & $\begin{array}{l}\text { Krim } \\
\text { Barang }\end{array}$ \\
\hline 11 & PPN 03 & $\begin{array}{l}\text { PPU } \\
\text { p0001304 }\end{array}$ & Kecap Asin & $\begin{array}{l}\text { Bahan } \\
\text { Polok }\end{array}$ & $2019-02-28$ & Lokal & Botal & - & $\begin{array}{l}\text { 135un } \\
\text { Liter }\end{array}$ & $P_{q}, 8,000$ & ${ }^{20202-12-}$ & 100 & $\begin{array}{r}R_{\varphi} \\
800,000\end{array}$ & $\begin{array}{l}\text { Krim } \\
\text { Barang }\end{array}$ \\
\hline 12 & PPu 03 & $\begin{array}{l}\text { PPM } \\
\text { P0001305 }\end{array}$ & Terigu & $\begin{array}{l}\text { Bahan } \\
\text { Polokik }\end{array}$ & 902.28 & wa & P & - & $\begin{array}{l}1 \mathrm{kllo} \\
\text { Gram }\end{array}$ & Rq. 8.000 & $\frac{2022-12-2}{30}$ & 100 & $\begin{array}{r}R_{p} \\
800.000\end{array}$ & $\begin{array}{l}\text { Krim } \\
\text { Barang }\end{array}$ \\
\hline 13 & PPM 03 & $\begin{array}{l}\text { PPH } \\
\text { P0001307 }\end{array}$ & Mingak & $\begin{array}{l}\text { Bahan } \\
\text { Polokik }\end{array}$ & $2019-02.28$ & Lobal & Botal & - & $\begin{array}{l}\text { 14in } \\
\text { Liter }\end{array}$ & $\begin{array}{r}P_{0} \\
21,500\end{array}$ & $\frac{2020.12-}{30}$ & 100 & $\begin{array}{r}R_{p} \\
2,150,000\end{array}$ & $\begin{array}{l}\text { Krim } \\
\text { Barang }\end{array}$ \\
\hline 14 & PPW 03 & $\begin{array}{l}\text { PPU } \\
\text { P001309 }\end{array}$ & Kocang Io & $\begin{array}{l}\text { Bahan } \\
\text { Potrok }\end{array}$ & $2019-02-28$ & Hema & Pos & - & $\begin{array}{l}1 \mathrm{Kll} \\
\text { Gram }\end{array}$ & $\begin{array}{r}P_{\varphi} \\
15,000\end{array}$ & $\frac{2022-12-}{30}$ & 100 & $\begin{array}{r}R_{p} \\
1,500,000\end{array}$ & $\begin{array}{l}\text { Krim } \\
\text { Baramg }\end{array}$ \\
\hline
\end{tabular}

Gambar 8. Halaman Data Barang Masuk

\section{Halaman Data Barang Keluar}

Halaman ini merupakan halaman yang digunakan untuk menampilkan datadata barang keluar yang ada di gudang yang telah di ambil toko untuk stok penjualanan berikutnya.

\begin{tabular}{|c|c|c|c|c|c|c|c|c|c|c|c|c|c|c|}
\hline \multicolumn{2}{|c|}{ PII } & $T$ & if & $\rightarrow \mathrm{H}$ & ncilan! & & & & & & \multicolumn{4}{|c|}{$\begin{array}{l}\text { Perum Opi } \\
\text { Ialan opi haya - Jakataning }\end{array}$} \\
\hline & & BARANG & MASUK & IARANG KELI & KELUAR & & & & & & & & & \\
\hline \multicolumn{15}{|c|}{ DATA BARANG MASUK } \\
\hline HO & $\begin{array}{c}\text { KODE } \\
\text { PLMASOK }\end{array}$ & $\begin{array}{l}\text { KODE } \\
\text { BARANG }\end{array}$ & $\begin{array}{l}\text { NAMA } \\
\text { EARANG }\end{array}$ & KATEGORI & $\begin{array}{l}\text { TANGGAL } \\
\text { PERMINTAAN }\end{array}$ & МЕREK & $\begin{array}{l}\text { SAFUAN } \\
\text { JENIS }\end{array}$ & $\begin{array}{l}\text { VOLUME } \\
\text { DAAANG }\end{array}$ & ISI BRG & $\begin{array}{l}\text { HAREA } \\
\text { BARANG }\end{array}$ & $\begin{array}{c}\text { EXPAED } \\
\text { ERG }\end{array}$ & $\begin{array}{l}\text { JUMLAH } \\
\text { PERMINTAAH }\end{array}$ & $\begin{array}{l}\text { FOTAL } \\
\text { HARGA }\end{array}$ & АK\$ \\
\hline 1 & PPM OS & $\begin{array}{l}\text { PPMD } \\
\text { Peoson } \\
0.0501\end{array}$ & Bur Band & $\begin{array}{l}\text { Eatan } \\
\text { Potook }\end{array}$ & 2019.03 .04 & $\begin{array}{l}\text { Eluo } \\
\text { Band }\end{array}$ & Kaleng & . & $2500 \mathrm{~ms}$ & $\begin{array}{r}R p \\
11,000\end{array}$ & $\begin{array}{l}2022=120 \\
30\end{array}$ & 100 & $\begin{array}{l}R_{p} \\
1.100 .000\end{array}$ & $\begin{array}{l}\text { Kerim } \\
\text { Barang }\end{array}$ \\
\hline 2 & PFMO1 & 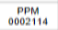 & $\begin{array}{c}\text { Makáanil } \\
\text { Keju }\end{array}$ & Snack & 2019.02 .213 & $\begin{array}{c}B 0 \\
\text { snack }\end{array}$ & Pos & . & $1000 \mathrm{~ns}$ & Rp 4,500 & $2022-12$. & 200 & 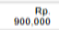 & $\begin{array}{c}\text { Kirim } \\
\text { Berano }\end{array}$ \\
\hline 3 & PPMO1 & $\begin{array}{c}\mathrm{PPM} \\
0002113\end{array}$ & $\begin{array}{l}\text { Kagang } \\
\text { Paddas }\end{array}$ & Snack & $2010-92-24$ & $\underset{\substack{\text { De } \\
\text { shask }}}{ }$ & $\mathrm{P}_{\mathrm{Gs}}$ & . & $2500 \mathrm{~ns}$ & 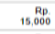 & $\begin{array}{l}2022-12- \\
30\end{array}$ & 190 & 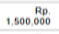 & 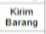 \\
\hline 4 & PFMO1 & $\begin{array}{c}\text { FPM } \\
0002112\end{array}$ & $\begin{array}{l}\text { Kaceno } \\
\text { nawang }\end{array}$ & Snack & $2019-02 \cdot 28$ & $\begin{array}{c}\text { Dón } \\
\text { snack }\end{array}$ & Pess & . & $2500 \mathrm{no}$ & $\begin{aligned} & \mathrm{Rp}_{\mathrm{p}} \\
& 10,000\end{aligned}$ & $\begin{array}{l}2022-12 x \\
30\end{array}$ & 250 & $\begin{aligned} & \begin{array}{r}\bar{R}_{p} \\
2.500 .000\end{array}\end{aligned}$ & $\begin{array}{c}\text { Kirim } \\
\text { Barang }\end{array}$ \\
\hline s & PPMO1 & $\stackrel{P P M}{0.002111}$ & $\begin{array}{l}\text { Korialk } \\
\text { Balado }\end{array}$ & Snack & $2019.02 .21 !$ & $\frac{D C}{\text { Snack }}$ & $\rho_{\mathrm{es}}$ & & $2500 \mathrm{~ms}$ &  & $\frac{2022-12-}{30}$ & 200 & 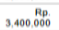 & $\begin{array}{l}\text { Kinim } \\
\text { Barang }\end{array}$ \\
\hline G & PPMO O1 & $\begin{array}{c}\text { ppm } \\
0.002109\end{array}$ & $\begin{array}{l}\text { Kontiak } \\
\text { Kentang }\end{array}$ & Snack & $2019-02.28$ & $\begin{array}{c}\text { Do } \\
\text { Shack }\end{array}$ & pes & . & $2500 \mathrm{~ns}$ & $\begin{array}{r}\mathrm{Rp} \\
10,000\end{array}$ & $\begin{array}{c}2022: 12{ }^{20} \\
30\end{array}$ & 100 & $\begin{array}{r}R_{p} \\
1.000,000\end{array}$ & $\begin{array}{l}\text { Kerinim } \\
\text { Bartang }\end{array}$ \\
\hline 7 & PFM OP & $\begin{array}{c}\text { PPM } \\
00022110\end{array}$ & Min Lid & Snack & $2619-02-28$ & $\begin{array}{c}D C \\
\text { Snack }\end{array}$ & $\mathrm{Pas}$ & . & $1060 \mathrm{~ns}$ & सिp $5 ., 000$ & $\begin{array}{c}2022-12 x \\
30\end{array}$ & 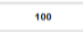 & $\begin{array}{r}\beta_{p} \\
500.000\end{array}$ & $\begin{array}{c}\text { Kirim } \\
\text { Bartano } \\
\end{array}$ \\
\hline 8 & PPMO1 & $\begin{array}{c}\mathrm{PPM} \\
0002100\end{array}$ & Kuping Galah & Snack & $2010-02.24$ & $\begin{array}{c}\text { DC } \\
\text { Shaack } \\
\end{array}$ & pes & . & $2500 \mathrm{~ns}$ & $\begin{array}{c}\mathrm{Rp}_{0} \\
13,500 \\
\end{array}$ & $\begin{array}{c}2022-12- \\
30\end{array}$ & 100 & 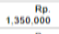 & 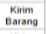 \\
\hline 9 & PFM 03 & 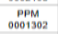 & $\begin{array}{l}\text { Tepung } \\
\text { Jagung }\end{array}$ & $\begin{array}{l}\text { Eatan } \\
\text { Petook }\end{array}$ & $2019-02: 28$ & $\begin{array}{l}\text { Gula } \\
\text { Merat }\end{array}$ & Pos & . & $3500 \mathrm{~ms}$ & Rp. 7,500 & $\begin{array}{l}2022.122 \\
30\end{array}$ & 400 & $\begin{array}{r}R_{p_{p}} \\
750,000\end{array}$ & $\begin{array}{l}\text { Kerim } \\
\text { Barang }\end{array}$ \\
\hline 10 & PFM Os & $\begin{array}{c}\text { PPM } \\
0601303\end{array}$ & Kesap Manis & $\begin{array}{l}\text { 县hán } \\
\text { Pokok }\end{array}$ & 2019.02 .21 & $\begin{array}{c}\text { aula } \\
\text { Merah }\end{array}$ & Eotal & & 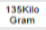 & Rp 7,500 & \begin{tabular}{|c|}
$2022-12-$ \\
30
\end{tabular} & 100 & 750.000 & $\begin{array}{l}\text { Kenim } \\
\text { Berang }\end{array}$ \\
\hline "1 & PFM 03 & $\begin{array}{c}\text { PPM } \\
00001304\end{array}$ & Koesap Asin & $\begin{array}{l}\text { Earan } \\
\text { Potoot }\end{array}$ & 2019.02 .28 & Lokal & Eatal & & $\begin{array}{l}135 \text { ssmin } \\
\text { Lhert }\end{array}$ & Rp 8, 8,000 & $\begin{array}{c}2022+12= \\
30\end{array}$ & 100 & $\begin{array}{c}R_{p} p \\
800,000\end{array}$ & $\begin{array}{c}\text { Kirim } \\
\text { Bartang }\end{array}$ \\
\hline 12 & PFM 05 & $\begin{array}{c}\text { FPM } \\
0001305\end{array}$ & $\begin{array}{l}\text { Teppuno } \\
\text { Tanguu }\end{array}$ & $\begin{array}{l}\text { Eatana } \\
\text { Fotok }\end{array}$ & $2010.02 .2 b$ & Mitia & Pos & & $\begin{array}{l}\text { ikio } \\
\text { Oram }\end{array}$ & $\overline{\bar{R}} \mathbf{0 . 0 0 6}$ & $\begin{array}{l}2022-120 \\
30\end{array}$ & 100 & $\begin{array}{c}\bar{F}_{p} \\
000.000\end{array}$ & $\begin{array}{l}\text { Kirim } \\
\text { garang }\end{array}$ \\
\hline 13 & РPM 03 & $\begin{array}{c}P P M \\
8001307\end{array}$ & Mnyak & $\begin{array}{l}\text { Eatab } \\
\text { Pókók }\end{array}$ & 2019.02 .28 & Loka! & 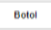 & . & $\begin{array}{l}\text { IMil } \\
\text { Liter }\end{array}$ & $\begin{array}{r}P{ }^{P 0} \\
21,500\end{array}$ & $\frac{2022-12-}{30}$ & 400 & $\begin{array}{r}R_{0} \\
2,150,900\end{array}$ & 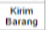 \\
\hline 14 & Рем OS & $\begin{array}{c}\text { PFM } \\
0001309\end{array}$ & Kacano lio & $\begin{array}{l}\text { Eahan } \\
\text { Potok }\end{array}$ & $2019-02.20$ & Mama & Pos & . & $\begin{array}{l}\text { Iikio } \\
\text { Gram }\end{array}$ & $\begin{array}{r}\mathrm{Rp}_{\mathrm{p}} \\
15,000\end{array}$ & \begin{tabular}{|c|}
$20022-42=$ \\
30
\end{tabular} & 100 & $\begin{array}{c}R_{p} \\
1.500 .000\end{array}$ & $\begin{array}{c}\text { Kirim } \\
\text { Barang }\end{array}$ \\
\hline
\end{tabular}

Gambar 9. Halaman Data Barang Keluar

\section{Halaman Bagian Toko}

Berikut penjelasan beberapa halaman yang terdapat di toko, yaitu terdiri dari Halaman Permintaan Barang. Pada halaman ini digunakan untuk menampilkan data-data pemasok yang dapat dilakukan sebagai permintaan 
barang yang dibutuhkan oleh toko ke pemasok pada halaman ini toko dapat memutuskan barang apa yang akan di pinta berdasarkan dat penjualanan yang ada.

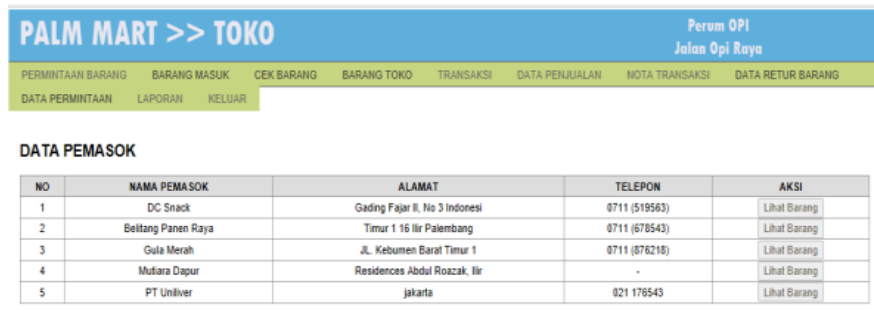

\section{Gambar 10. Halaman Data Permintaan Barang}

10. Halaman Barang Masuk

Pada halaman ini merupakan halaman barang masuk yang digunakan oleh toko untuk menampilkan yang telah dikirim oleh pemasok ke toko sehingga barang-barang dapat diketahui dengan baik.

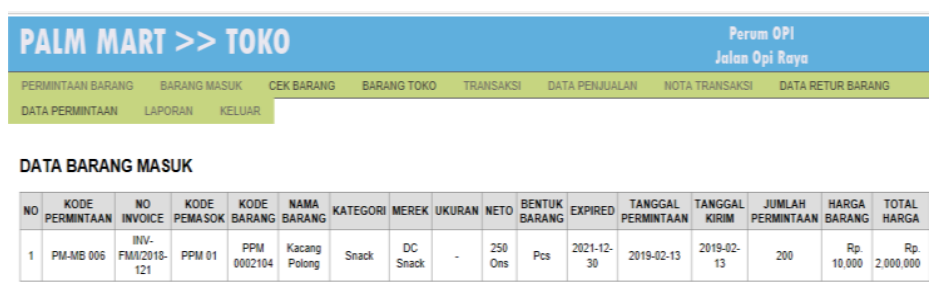

\section{Gambar 11 Halaman Data Barang Masuk}

\section{Halaman Data Cek Barang}

Halaman data cek barang merupakan halaman yang telah di cek dan masuk ke dalam halaman yang telah di cek dan akan ada peringatan apakan barang tersebut terdapat retur, jika terdapat maka akan dikirim secara langsung dan barang dapat dikirim ke gudang untuk disimpan sebagai stok barang. 


\section{Jurnal Pengembangan Sistem Informasi dan Informatika}

Vol. 1, No. 3, July 2020 e-ISSN: 2746-1335

http://journal.jis-institute.org/index.php/jpsii/index

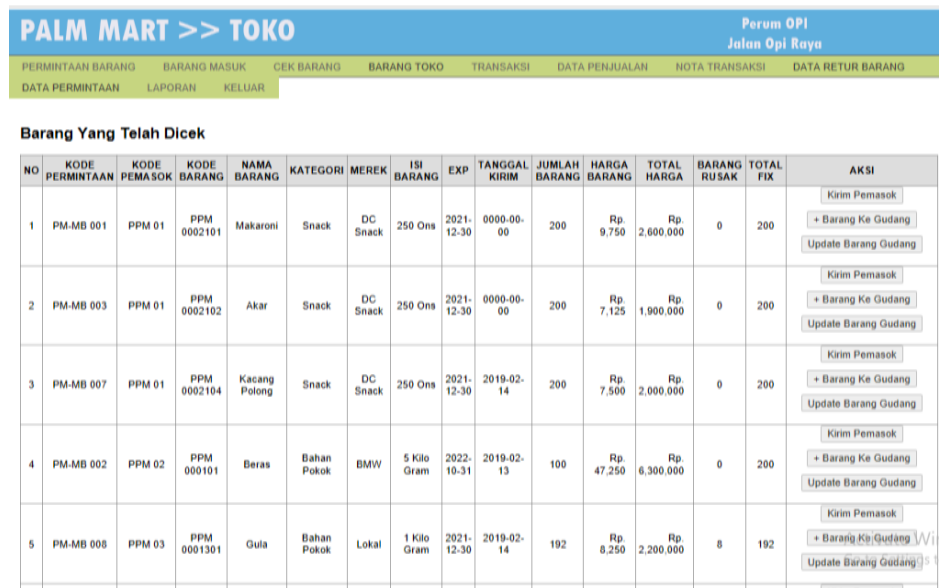

Gambar 12. Halaman Data Cek Barang

\section{Halaman Barang Toko}

Pada Halaman ini menampilkan data-data barang yang ada di Toko Palm Mart dan setiap barang memiliki keterangan berbeda dan memiliki tombol beli yang dapat dilakukan untuk melakukan transaksi penjualanan yang ada di Toko Palm Mart Palembang.

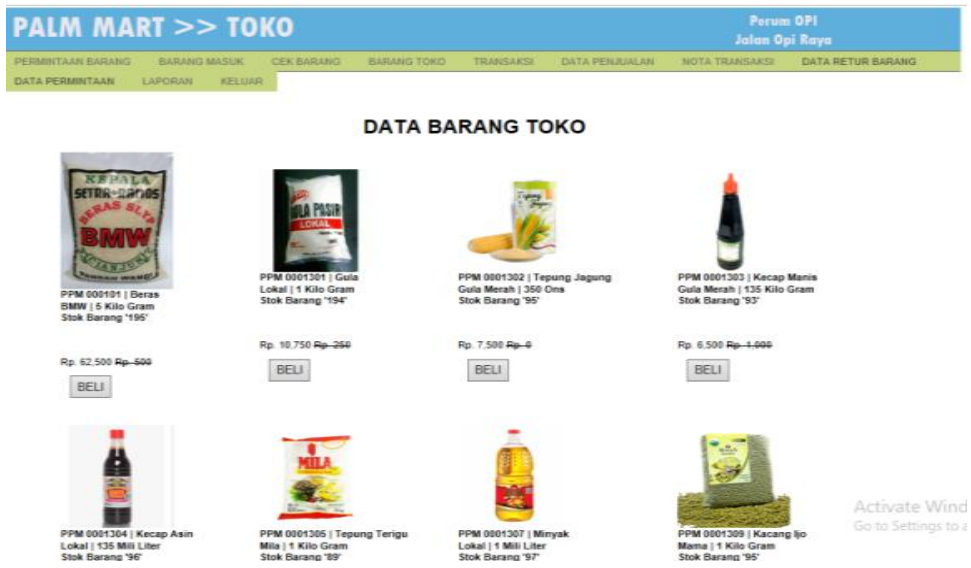

Gambar 13. Halaman Barang Toko

13. Halaman Transaksi

Halaman ini digunakan untuk melakukan transaksi yang terjadi di toko, dan pada halaman ini memiliki link cetak yang dapat melakukan cetak struk dalam setiap transaksi. 
http://journal.jis-institute.org/index.php/jpsii/index

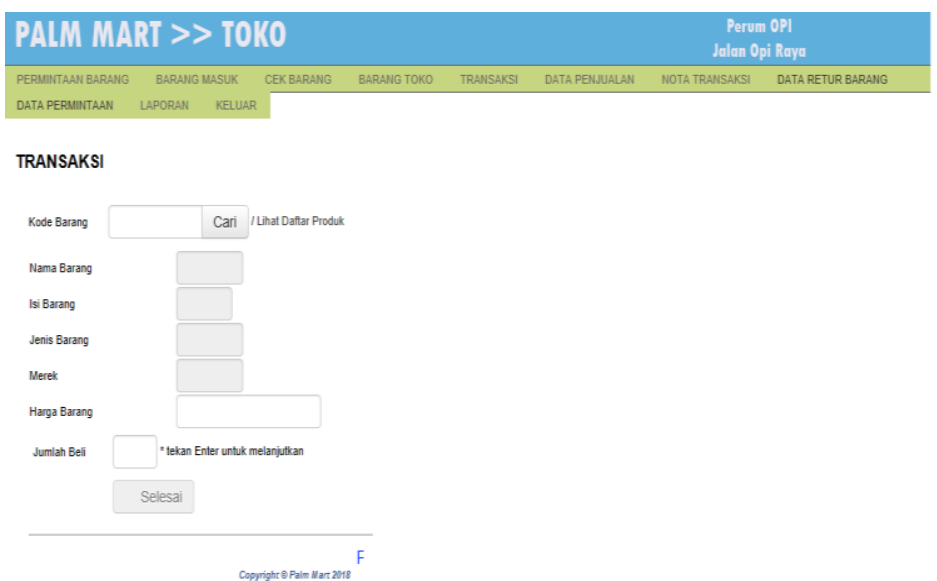

Gambar 14. Halaman Transaksi

14. Halaman Data Penjualan

Pada Halaman ini digunakan untuk menampilkan data-data barang yang telah melakukan transaksi di Toko Palm Mart.

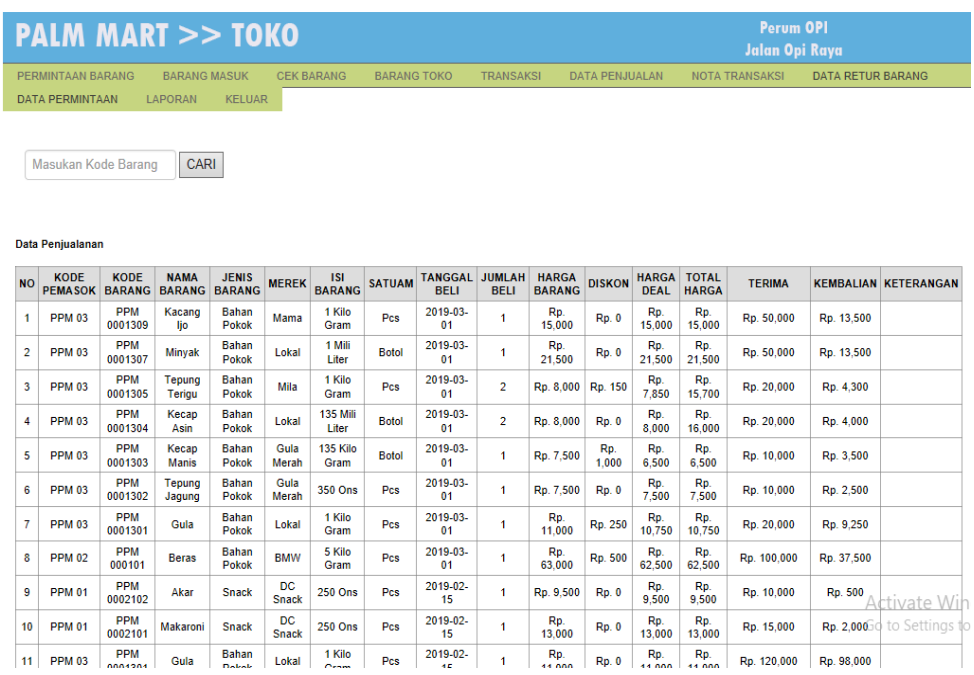

Gambar 15. Halaman Data Penjualan

15. Halaman Nota Transaksi

Pada Halaman ini digunakan untuk menampilkan struk- struk transaksi yang telah terjadi yang ada di Toko Palm Mart sehingga jika terjadi kesalahan dapat mencetak ulang struk yang ada. 


\section{Jurnal Pengembangan Sistem Informasi dan Informatika}

Vol. 1, No. 3, July 2020 e-ISSN: 2746-1335

http://journal.jis-institute.org/index.php/jpsii/index

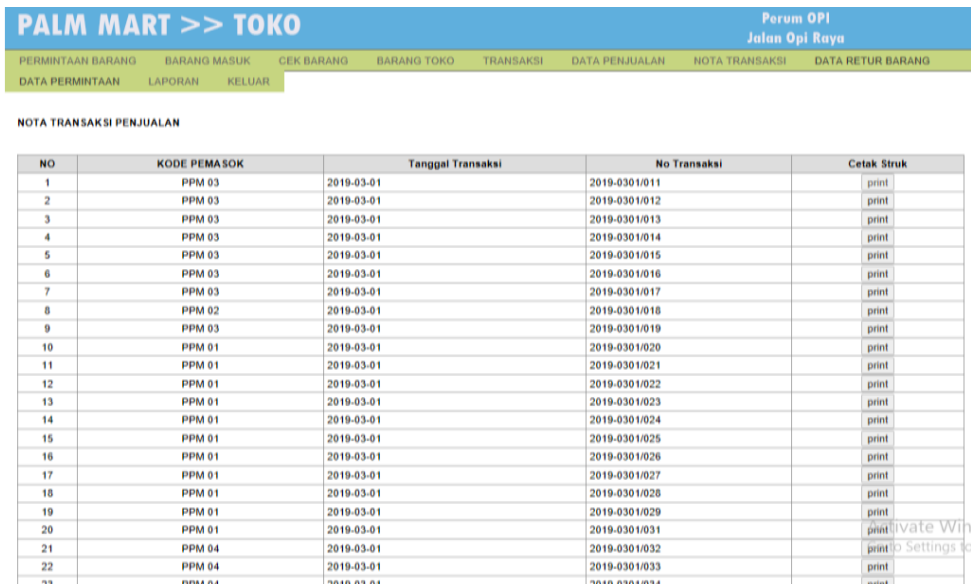

Gambar 16. Halaman Nota Transaksi

16. Halaman Data Retur Barang

Halaman ini dilakukan untuk menampilkan retur barang yang ada di toko Palm Mart Palembang.

\begin{tabular}{|c|c|c|c|c|c|c|c|c|c|c|c|c|c|}
\hline \multicolumn{9}{|c|}{ PALM MART $>>$ TOKO } & \multicolumn{5}{|c|}{$\begin{array}{l}\text { Perum OPI } \\
\text { Jalan Opi Raya }\end{array}$} \\
\hline \multirow{2}{*}{\multicolumn{3}{|c|}{$\begin{array}{l}\text { PERMINTAAN BARANG } \\
\text { DATA PERMINTAAN }\end{array}$}} & BARANG MASUK & \multirow[t]{2}{*}{ CEK BARANG } & \multicolumn{2}{|c|}{ BARANG TOKO } & \multirow[t]{2}{*}{ TRANSAKSI } & \multirow{2}{*}{\multicolumn{2}{|c|}{ DATA PENJUALAN }} & \multicolumn{2}{|c|}{ NOTA TRANSAKSI } & \multicolumn{2}{|c|}{ DATA RETUR BARANG } \\
\hline & & & KELUAR & & & & & & & & & & \\
\hline \multicolumn{14}{|c|}{ Data Retur Gudang } \\
\hline No & $\begin{array}{c}\text { KODE } \\
\text { PEMASOK }\end{array}$ & $\begin{array}{c}\text { KODE } \\
\text { BARANG }\end{array}$ & NO RETUR & $\begin{array}{l}\text { NAMA } \\
\text { BARANG }\end{array}$ & KATEGORI & MEREK & \begin{tabular}{|c|} 
BERAT \\
BARANG
\end{tabular} & $\begin{array}{l}\text { SATUAN } \\
\text { JENIS }\end{array}$ & $\begin{array}{l}\text { TANGGAL } \\
\text { RETUR }\end{array}$ & \begin{tabular}{c|} 
RETUR \\
GUDANG
\end{tabular} & $\begin{array}{c}\text { HARGA } \\
\text { BARANG }\end{array}$ & \begin{tabular}{|l|} 
TOTAL \\
RETUR
\end{tabular} & KETERANGAN \\
\hline 1 & PPM 05 & $\begin{array}{c}\text { PPM } \\
000501\end{array}$ & RTPM-UNI/ & Blue Band & $\begin{array}{l}\text { Bahan } \\
\text { Pokok }\end{array}$ & $\begin{array}{l}\text { Blue } \\
\text { Band }\end{array}$ & 250 Ons & Kaleng & $2019-03-04$ & 2 & Rp. 9,000 & $\begin{array}{c}\text { Rp. } \\
18,000\end{array}$ & $\begin{array}{c}\text { Barang } \\
\text { Rusak//Cacat }\end{array}$ \\
\hline 2 & PPM 03 & $\begin{array}{c}\text { PPM } \\
0001301\end{array}$ & RPM/2019/XXIV & Gula & $\begin{array}{l}\text { Bahan } \\
\text { Pokok }\end{array}$ & Lokal & 1 Kilo Gram & Pcs & 2019-03-01 & 8 & Rp. 8,250 & $\underset{\text { Rpp. }}{\text { R6,000 }}$ & $\begin{array}{c}\text { Barang } \\
\text { Rusak/Cacat }\end{array}$ \\
\hline 3 & PPM 04 & $\begin{array}{c}\text { PPM } \\
0002506\end{array}$ & RPM/201902/KXVIII & | Lada Hitam & $\begin{array}{l}\text { Bumbu } \\
\text { Masak }\end{array}$ & \begin{tabular}{c|c} 
Mutiara \\
Dapur
\end{tabular} & 100 Ons & Boto & $2019-03-01$ & 1 & Rp. 15,000 & $\begin{array}{c}\text { Rp. } \\
15,000\end{array}$ & $\begin{array}{c}\text { Barang } \\
\text { Rusak/Cacat }\end{array}$ \\
\hline 4 & PPM 04 & $\begin{array}{c}\text { PPM } \\
0002502\end{array}$ & RPM/2019:XXXIII & Kemiri & $\begin{array}{l}\text { Bumbu } \\
\text { Masak }\end{array}$ & Lokal & 250 Ons & Pcs & 2019-03-01 & 1 & Rp. 12,375 & $\begin{array}{c}\mathrm{Rp} \\
12,375\end{array}$ & $\begin{array}{c}\text { Barang } \\
\text { Rusakiczacat }\end{array}$ \\
\hline 5 & PPM 04 & $\begin{array}{l}\text { PPM } \\
0002507\end{array}$ & RPMI201902/XXIX & Garam & $\begin{array}{l}\text { Bumbu } \\
\text { Masak }\end{array}$ & $\begin{array}{l}\text { Mutiara } \\
\text { Dapur }\end{array}$ & 500 Ons & Pcs & 2019-03-01 & 5 & Rp. 5,000 & $\underset{25,000}{R .}$ & $\begin{array}{c}\text { Barang } \\
\text { Rusak/Cacat }\end{array}$ \\
\hline 6 & PPM 04 & $\begin{array}{c}\text { PPM } \\
0002505\end{array}$ & RPM/201902/XXVI & Lada Putih & $\begin{array}{l}\text { Bumbu } \\
\text { Masak }\end{array}$ & \begin{tabular}{c|c} 
Mutiara \\
Dapur
\end{tabular} & 100 Ons & Botd & 2019-03-01 & 3 & Rp. 8,500 & $\begin{array}{c}\text { Rp. } \\
25,500\end{array}$ & $\begin{array}{c}\text { Barang } \\
\text { Rusak/Cacat }\end{array}$ \\
\hline 7 & PPM 04 & $\begin{array}{c}\text { PPM } \\
0002508\end{array}$ & RPM/201902/XXX & $\begin{array}{c}\text { Bubuk Kaldu } \\
\text { Jamur }\end{array}$ & $\begin{array}{l}\text { Eumbu } \\
\text { Masak }\end{array}$ & $\begin{array}{l}\text { Mutiara } \\
\text { Dapur }\end{array}$ & 100 Ons & Boto & 2019-03-01 & 4 & Rp. 5,000 & $\begin{array}{c}\mathrm{Rp} \\
20,000\end{array}$ & $\begin{array}{c}\text { Barang } \\
\text { Rusak/Cacat }\end{array}$ \\
\hline 8 & PPM 03 & $\begin{array}{c}\text { PPM } \\
0001304\end{array}$ & RPM/201902/X & Kecap Asin & $\begin{array}{l}\text { Bahan } \\
\text { Pookok }\end{array}$ & Lokal & 135 Mili Liter & Botd & $2019-02-28$ & 2 & Rp. 5,000 & $\begin{array}{c}\text { Rp. } \\
10,000\end{array}$ & $\begin{array}{c}\text { Barang } \\
\text { Rusak//Cacat }\end{array}$ \\
\hline 9 & PPM 04 & $\begin{array}{c}\text { PPM } \\
0002512\end{array}$ & RPM/201902/XV & asam jawa & $\begin{array}{l}\text { Bumbu } \\
\text { Masak }\end{array}$ & $\begin{array}{l}\text { Mutiara } \\
\text { Dapur }\end{array}$ & 150 Ons & Pcs & $2019-02-28$ & 1 & Rp. 14,000 & $\begin{array}{c}\text { Rp. } \\
14,000\end{array}$ & $\begin{array}{c}\text { Barang } \\
\text { Rusak/Cacat }\end{array}$ \\
\hline 10 & PPM 01 & $\begin{array}{c}\text { PPM } \\
0002113\end{array}$ & RPM/201902/XX & Kacang Pedas & Snack & DC Snack & 250 Ons & Pcs & 2-28 & 10 & Rp. 12,500 & $\begin{array}{c}\text { Rp. } \\
125,000\end{array}$ & $\begin{array}{c}\text { Barang } \\
\text { Rusak//Cacat }\end{array}$ \\
\hline 11 & PPM 03 & $\begin{array}{c}\text { PPM } \\
0001309\end{array}$ & RPM/201902NII & Kacang ljo & $\begin{array}{l}\text { Bahan } \\
\text { Pokok }\end{array}$ & Mama & 1 Kilo Gram & Pcs & $2019-02-28$ & 2 & Rp. 13,000 & $\begin{array}{c}\text { Rp. } \\
26,000\end{array}$ & $\begin{array}{c}\text { Barang } \\
\text { Rusak//Cacat }\end{array}$ \\
\hline 12 & PPM 01 & $\begin{array}{c}\text { PPM } \\
0002108\end{array}$ & RPM/201902л & Kuping Gajah & Snack & DC Snack & 250 Ons & Pos & $2019-02-28$ & 7 & Rp. 12,000 & $\begin{array}{r}\text { Rp. } \\
84,000\end{array}$ & ACtisarang Wi \\
\hline 13 & PPM 03 & $\begin{array}{c}\text { PPM } \\
0001302\end{array}$ & RPM/201902/XII & $\begin{array}{l}\text { Tepung } \\
\text { Jagung }\end{array}$ & $\begin{array}{l}\text { Bahan } \\
\text { Pokokok }\end{array}$ & $\begin{array}{l}\text { Gula } \\
\text { Merah }\end{array}$ & 350 Ons & Pcs & $2019-02-28$ & 2 & Rp. 5,000 & $\begin{array}{c}\text { Rp. } \\
10,000\end{array}$ & $\begin{array}{l}\text { o to } \text { Barang gs } \\
\text { Rusakicacat }\end{array}$ \\
\hline
\end{tabular}

Gambar 17. Halaman Retur Barang

17. Halaman Data Permintaan

Halaman ini merupakan halaman untuk menampilkan data-data permintaan barang yang dilakukan oleh bagian toko ke bagian gudang. 
Jurnal Pengembangan Sistem Informasi dan Informatika

Vol. 1, No. 3, July 2020 e-ISSN: 2746-1335

http://journal.jis-institute.org/index.php/jpsii/index

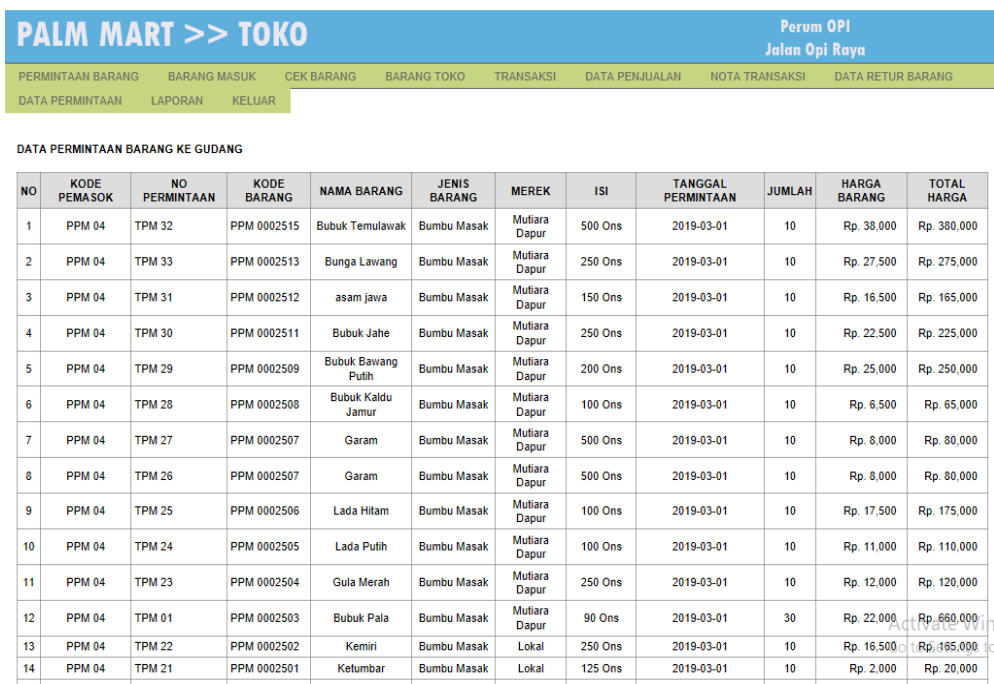

Gambar 18. Halaman Permintaan

18. Halaman Laporan

Pada halaman ini menjelaskan tentang semua data-data laporan yang ada di Toko.

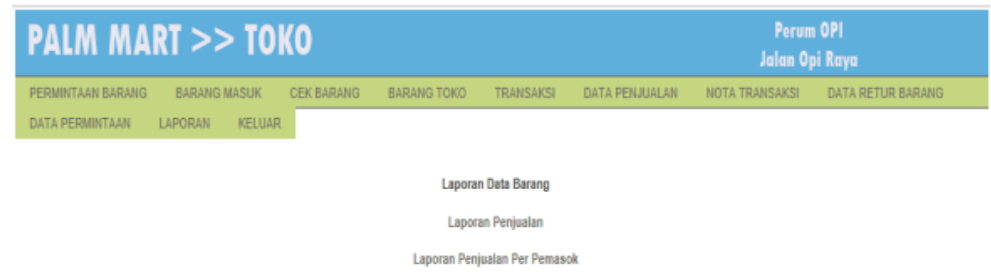

Gambar 19. Halaman Laporan

\section{KESIMPULAN}

Dari uraian yang telah dikemukakan maka dapat disimpulkan bahwa pengembangan sitem informasi pada mini market Palm Mart telah 
menerapkan konsep muti-tier yang dibuktikan dengan hasil pengembangan yang memiliki beragam level pengguna dalam proses bisnis yang dijalankan pada sistem informasi. sitem informasi yang dihasilkan juga memiliki level pengguna yang terdiri dari pemasok, bagian gudang dan bagian penjualan (tokok).

\section{DAFTAR PUSTAKA}

Abdul Kadir. 2008. Tuntunan Praktis Belajar Database Menggunakan MySQL. Yogyakarta : C.V Andi Offset

Al-Bahra bin Ladjamudin. 2005. Analisis dan Desain Sistem Informasi. Yogyakarta : Graha Ilmu.

Al Fatta, Hanif. 2007. Analisis dan Perancangan Sistem Informasi. Yograkarta: CV. Andi Ofset

Agus Mulyanto, 2009. Sistem Informasi Konsep dan Aplikasi. Yogyakarta: Pustaka Pelajar

Agus Saputra. 2011. Trik dan Solusi Jitu Pemrograman PHP. Jakarta: PT. Elex Media Komputindo.

A.S Rosa dan M. Shalahuddin. 2014. Rekayasa Perangkat Lunak Struktur dan. Berorientasi Objek. Bandung : Informatika.

Jogiyanto, H.M. 2005. Analisa dan Desain Sistem Informasi: Pendekatan. Terstruktur Teori dan Praktik Aplikasi Bisnis. Yogyakarta: ANDI.

Laudon. Kenneth C., dan Laudon. Jane P. 2007. Management Information System. 10th ed, Jakarta: Salemba Empat.

Nazir, Moh. 2009. Metode Penelitian. Jakarta: Ghalia Indonesia.

Raymond McLeod,Jr. 2001. Sistem Informasi Edisi 7 Jilid 2. Prenhallindo. Jakarta.

Simarmata, Janner. 2010. Rekayasa Perangkat Lunak. Yogyakarta. Andi Ofset

Sutarman. 2009. Pengantar teknologi Informasi. Jakarta : Bumi Aksara 